\title{
Introduction to Special Series on Information Exchange in Electronic Markets: New Business Models
}

\author{
Dag H. Olsen \\ Agder University College, Norway
}

dag.h.olsen@hia.no

\author{
Sandeep Purao \\ Georgia State University, USA
}

spurao@gsu.edu

\section{Series Overview}

\begin{abstract}
Advances in Internet technologies and related software increasingly drive a large numbers of businesses. A core component of these new businesses is the information exchange between business partners or clients. For example, issues of information exchange form the basis of much ebrokerage and on-line auction markets. For B2B ebusiness and supply chain, exchange of information among trading partners using vehicles such as XML/EDI is an essential consideration. In fact, we see the rise of new markets for information aggregation, refinement and targeting that are formed on the foundation of information exchanges. Current research suggests that consumers use the web for information gathering even more than for electronic shopping. A number of new businesses have been launched over the last few years for the sole purpose of informing potential buyers, often with only advertising and endorsements as the only revenue sources.
\end{abstract}

Few conceptualizations of the underlying business models have been proposed, in part because our investigations have focused on the technology instead of issues of information exchange. The purpose of this special issue is to stimulate original conceptual and empirical research for understanding the rise, evolution and deployment of business models for information exchanges in electronic markets.

\footnotetext{
Material published as part of this journal, either on-line or in print is copyrighted by the publisher of Informing Science. Permission to make digital or paper copy of part or all of these works for personal or classroom use is granted without fee provided that the copies are not made or distributed for profit or commercial advantage AND that copies 1) bear this notice in full and 2) give the full citation on the first page. It is permissible to abstract these works so long as credit is given. To copy in all other cases or to republish or to post on a server or to redistribute to lists requires specific permission and payment of a fee. Contact Editor@inform.nu to request redistribution permission.
}

The three articles in this special series provide interesting new perspectives on business models of information exchange.

The article by Wijnhoven explores the problems of specifying information needs and evaluating retrieval results, and approaches these problems as information market problems. The article proposes information market service process models that link information suppliers and information buyers. These models consist of activities, information resources, controls and information flows. Intermediate information market services are important to match supply and demand of information challenging the notion of dis-intermediation. The markets are classified as pure markets, networks or hierarchies. The authors suggest design parameters for effective services in information markets on the wed and apply the parameters to analyze existing services. The proposals can serve as an extension of established models in electronic commerce to cope with the information commodities and data products.

The article by den Hengst and Sol explores the issue of interorganizational coordination structures. It describes guidelines to predict the impact of information and communication technology (ICT) on interorganizational coordination structures. The authors propose a framework consisting of three perspectives: coordination structures (the subject of research), the use of ICT (having the potential to change coordinating structures) and other aspects (influencing impact on coordination structures). The perspectives are further elaborated into elements. The three perspectives form the basis of a causal diagram, where directions and influencing impacts between the elements of the perspectives are described and supported by the literature review. The causal diagram can serve as a tool to 
Information exchange in electronic markets

understand the coordinating structures when ICT is introduced to support interorganizational coordination.

The article by Sannes proposes a framework for evaluating self-service banking concepts. The author explores the relationship between exchange of information and different models of value creation in the banking sector. The value network and value shop concepts of Stabell and Fjellstad are used to form this model. He finds that these concepts are consistent with self-service banking, and that the value chain concepts are inappropriate. A framework is proposed for evaluating the impact of the value configuration self-service banking. The conceptual model is further investigated light of the recent developments in banking to reach the conclusion that self-service banking is an immature business concept.

\section{Biographies}

Dag H. Olsen is Associate Professor of Information Systems at Agder University College, Norway. He teaches courses in e-business and IT and business development. Research subjects include e-business in SMEs, IT compe- tence and IT and business process development. His publications are in Decision Support Systems and ecommerce.

Sandeep Purao's research focuses on various aspects of information system design and development. His current research projects include reuse-based design, flexible information system design, empirical investigation of individual design behaviors, and information system design for electronic commerce. He has worked on projects dealing with object distribution design strategies, measurement for object-oriented design, document management and abstractions for system development knowledge. He continues to be interested in pedagogical issues for information system developers. Sandeep's research has appeared in Communications of the ACM, Journal of MIS, Decision Support Systems, DataBase, Information \& Management, Information Systems Journal, and Journal of Database Management among others. He serves on the editorial board of Journal of Database Management, Informing Science, has co-edited special issues for DataBase and Informing Science and is active in the WITS and HICSS communities. 